\title{
Foreword: A Major Oil Spill Here
}

Walking around in oil up to my knees on the shoreline of southern Chile in August 1975 was a sobering experience for a nature lover like me, particularly because I had just spent several weeks working along the essentially untouched coastline of south-central Alaska. Eventually, though, my practical, scientific nature took over, and I saw that there was a job to be done that I was uniquely qualified for, first academically and later on as a business person. Some of my students and business partners and I have been trying to understand how to respond to such incidents ever since.

I started keeping a fairly detailed diary a year or so before that, so I have a pretty good record of what went on at the oil spill in Chile and the ones that followed. This book is built from a mosaic of those diary notes, plus a little reminiscing about the more distant past. The incidents reported are all true. In a few instances, the time sequence has been changed slightly in order to smooth the telling of the story. Also, where appropriate, the names of certain individuals have been changed in order to protect their privacy.

I don't have a clue why I took all those notes; however, over time, pieces of the mosaic seemed to fit together as if predestined-pieces such as living in the rain forest in Alaska, the Black Tide of La Coruña, Spain, the plane crash, and on and on. The mosaic took on a near-final form as I walked the oil-soaked mud flats of the coastline of Saudi Arabia after the Gulf War oil spills of I99I. But I'm getting ahead of myself.

25 December 1978 -

On the beaches of Puerto Rico

The young Coast Guard petty officer, sweat pouring down his face, waved his arms emphatically while trying to direct traffic at the intersection of two dirt roads several yards behind the beach. Long lines of cars were backed up on both of the roads, with half of the impatient 
drivers honking on their horns. The traffic was a complete snarl on this Christmas holiday weekend on the north shore of Puerto Rico.

"There's been a major oil spill here!" he shouted his frustration, somehow thinking that this proclamation would clear the traffic. Then the cleanup of the No. 6 fuel oil that had spilled out of the barge Peck Slip and was impacting the beaches could begin in earnest.

We finally reached him and showed him our badges. He waved us on by. "Which way to the beach with the heavy oil?" I asked as we passed him. He pointed to the left, and we drove out of the traffic, following the ruts over the dunes and down to the beach where the cleanup workers were still gathering.

By then, we were doing this for a living: going to oil spills whenever and wherever they occurred if the U.S. Coast Guard needed some scientific support from our client, the National Oceanic and Atmospheric Administration (NOAA), to plan a response to the spill. We had been on worse assignments than Puerto Rico in December. This spill was fairly early in the game for us. We had only been at it for three and a half years, and we were still green and excited, glad to get the chance to go to the spill and make our contribution. So what if it was Christmas? We still had a lot to learn. We saw heavily oiled mangroves for the first time at that spill, and I was impressed by the transport of the dark black oil back out to sea by currents in the rip cells that developed all along the exposed sand beaches.

The science we pursue is called "coastal geomorphology," which means study of the shape, or form, of the coast, including how it has evolved. About thirty-five years ago, while still a graduate student at the University of Texas, I began my first scientific research project on an ocean shoreline, the coastal bend area of South Texas. I finished my dissertation on the geomorphological effects of hurricanes on the Texas coast and journeyed on to teaching positions at the universities of Massachusetts and South Carolina. At those schools, I was joined by an army of graduate students as we conducted studies of shorelines as far away as northern Alaska, southern Chile, and Kuwait.

When we started, understanding how the coast was made was almost virgin territory, at least in the United States. Hypotheses on how barrier islands evolve, how the tides and waves shape the coast, and how the storms change things were there for the alert observer to deduce, assuming enough examples had been seen and that the global processes had been properly accounted for. We were using what Comet (1 996) ${ }^{1}$ referred to as "one of Aristotle's two forms of logical inference"-namely, inductive reasoning from the observation of a generalized pattern or distribu- 
tion in order to develop a principle or law. In other words, we started with a large number of more or less random observations, not with a detailed data set on a specific topic. However, we did eventually try to figure out how to collect meaningful data sets to verify or disprove those deduced principles or laws.

The practical reasons for making such observations usually centered on environmental issues such as beach erosion and other forms of habitat destruction. The most meaningful observations were made by being there-we went by boat, by plane, by four-wheel drive vehicles, and by walking. We spent long hours in the sun and the wind and the rain, working out ways to make our observations more and more disciplined and useful.

Most of the observers I worked with were called to this field by some elemental communication with the Great Mystery or the Spirit Father (or whatever the people that beat us here-by about ten thousand years-called it). Over the years, we all came to love that part of the earth where the waves and the tides shape the land. It seemed as if we almost became a part of it ourselves.

The methods we used to pursue our dream of understanding how the coast was made are no longer in vogue, a kind of scientific future shock for people like me. The new dreamers who want to understand this phenomena will not be doing it by foot, by car, by plane, or by boat. They will be doing it with remotely sensed images and with computer models that churn out mathematical solutions to their theories. I just hope that the new searchers will somehow be able to feel it, smell it, and touch it the way we did.

Through all of our wanderings we noticed how the most remote and unmodified areas of the coastlines we studied were being rapidly encroached upon by humans and how the most populated areas were abused more and more over time. We tried to deal with these abuses each in our own way. Leaving the bigger, and no doubt much more significant, issues such as ground water depletion, global warming, and sea level rise to others, my immediate associates and I have focused on a problem more tangible and approachable, the impacts of oil spills.

It all started at the end of the earth, along the shoreline of Chile in the Strait of Magellan in the summer of 1975, and almost ended for me fifteen years later on a rock off Mitkof Island in southeast Alaska in the summer of 1990 . 
THIS PAGE INTENTIONALLY LEFT BLANK 